\title{
Trends and Conditions for the Formation of Profitability of Agricultural Enterprises: A Case Study of Lviv Region, Ukraine
}

\author{
Tetiana Shmatkovska ${ }^{1, *}$, Mykola Dziamulych ${ }^{2}$, Nataliia Vavdiiuk $^{3}$, Serhiy Petrukha ${ }^{4}$, Nataliia Koretska ${ }^{3}$, \\ Andrii Bilochenko 5 \\ ${ }^{1}$ Department of Accounting and Taxation, Lesya Ukrainka Volyn National University, Ukraine \\ ${ }^{2}$ Department of Economics, Lutsk National Technical University, Ukraine \\ ${ }^{3}$ Department of Management, Lutsk National Technical University, Ukraine \\ ${ }^{4}$ Department of Management in Construction, Kiev National University of Construction and Architecture, Ukraine \\ ${ }^{5}$ National Scientific Centre «Institute of Agrarian Economics» NAAS, Ukraine
}

Received December 22, 2021; Revised January 24, 2022; Accepted February 24, 2022

\section{Cite This Paper in the following Citation Styles}

(a): [1] Tetiana Shmatkovska, Mykola Dziamulych, Nataliia Vavdiiuk, Serhiy Petrukha, Nataliia Koretska, Andrii Bilochenko , "Trends and Conditions for the Formation of Profitability of Agricultural Enterprises: A Case Study of Lviv Region, Ukraine," Universal Journal of Agricultural Research, Vol. 10, No. 1, pp. 88 - 98, 2022. DOI: 10.13189/ujar.2022.100108.

(b): Tetiana Shmatkovska, Mykola Dziamulych, Nataliia Vavdiuk, Serhiy Petrukha, Nataliia Koretska, Andrii Bilochenko (2022). Trends and Conditions for the Formation of Profitability of Agricultural Enterprises: A Case Study of Lviv Region, Ukraine. Universal Journal of Agricultural Research, 10(1), 88 - 98. DOI: 10.13189/ujar.2022.100108.

Copyright $\mathrm{C} 2022$ by authors, all rights reserved. Authors agree that this article remains permanently open access under the terms of the Creative Commons Attribution License 4.0 International License

\begin{abstract}
In the article we investigate the problem of determining the main factors of increasing the profitability of agricultural enterprises in order to effectively use the resource potential of agricultural producers. In this study, we used a set of modern scientific methods, among which we highlight such methods as factor analysis, structural analysis, graphical and tabular methods, grouping methods, regression statistical analysis, etc. In particular, grouping methods are used in the study for the distribution of the researched enterprise's totality according to the special features of their functioning. Also in the process of our study regression, a statistical analysis method was used to build a regression model to assess the relationship of profit and revenue from agricultural enterprises with such factors as a capital ratio, the average annual amount of enterprise assets, the labour costs, and the number of material costs per unit of land area. Besides, in order to study the level of profitability of agricultural enterprises in terms of their organizational and legal forms of management, the scope of financial and economic activities as well as the unit of the occupied area, livestock and taking into account the products produced, we used the structural analysis method.
\end{abstract}

According to the results of the study, we found that the profitability of agricultural enterprises in the Lviv region of Ukraine depends on the characteristics of their versatility. Thus, according to the results of the study we proved, that the constructed multifactorial correlation and regression models allow us to make the conclusion about availability of the significant impact on the profitability of the security of the agricultural enterprises in Lviv region of Ukraine and the level of their intensification of the production activities. Based on the study, it can be argued that the profit of agricultural enterprises is a key indicator for the implementation of the process of agricultural production, and is one of the main criteria for the effectiveness of the agricultural sector. It is determined that the activity of agricultural enterprises is significantly influenced by external factors that are not directly related to the production activities of enterprises.

Keywords Profit, Profitability, Agricultural Enterprises, Multifactorial Regression Analysis 


\section{Introduction}

As it's known, the profitability of an enterprise is a key indicator of the efficiency of its economic activity. Of particular importance is that businesses must ensure maximum profit under the existing resource constraints, manifested in access to financial and credit resources, material support of the production process, and sufficient skills to perform the workforce's tasks. Therefore, only the optimal combination of all these components allows companies to ensure the appropriate level of profitability in market competition.

If we talk about the profitability of agricultural enterprises, it should be noted that it is the main condition for their technical and technological re-equipment, and accordingly - the efficient and stable operation, and development of an innovative model of agriculture [4]. Thus, we can talk about profitability as a basis for expanding the production of agricultural products based on the overall improvement of its quality, environmental friendliness, and technical excellence, which makes it possible to increase the competitiveness of agricultural enterprises in both domestic and foreign markets. In addition, it is necessary to note the significant role of profitability of agricultural enterprises as a basis for the socio-economic development of rural areas. It is no secret that successful agricultural producers largely solve the problems of employment of the rural population, and invest in the development of the necessary social infrastructure of the respective territorial communities within which these enterprises operate. That is, socially responsible business also needs resources that are provided through a high level of profitability.

At the same time, if we talk about the profitability of agricultural enterprises in Ukraine in modern conditions, it should be noted that there are structural problems with its provision for most businesses. Despite the overall increase in profitability of agricultural enterprises over the past decade, about $40 \%$ of them have problems ensuring their proper level, which results in a decrease in their financial stability, and bankruptcy. Therefore, solving the problem of increasing the profitability of agricultural enterprises in general, and price disparities requires the development of a set of regulatory measures for the agricultural market.

\section{Literature Review}

Research of the essence of profit as the main purpose of the enterprise, as well as its role in the system of economic indicators, the study of methods of its calculation and evaluation are covered in the leading works of scientists and practitioners, which include I. A. Berzhanir [3], O. V. Khmelevskyi [7], L. A. Kostyrko [10], S. V. Mochernyi [14], M. F. Ohiichuk [15], T. V. Osipova [16], O. V. Stashchuk [20] and others. General issues of ensuring the profitability of agricultural enterprises and their financial management in terms of improving the efficiency and effectiveness of their operation are set out in the works of such researchers as V. H. Andriichuk [1], R. R. Antoniuk [2], M. Y. Khorunzhyi [8], L. A. Lakhtionova [11], L. Yu. Melnyk [13], P. T. Sabluk [19], V. M. Zhmailov [22], V. Yurchyshyn [24] and others.

In addition, it is necessary to highlight the study of L. L. Melnyk, who determined that the profitability of agricultural enterprises is formed under the influence of a number of factors. A prominent place in their composition belongs to the external factor - market prices for products and state support. At the same time, the quality of management is especially important in the system of internal factors influencing profitability. After all, in the conditions of economic and legal sovereignty, managers of all levels have the opportunity to show innovation and creativity in both production and commercial activities. This is evidenced by the experience of the enclave of highly profitable agricultural enterprises that operate in the same market and business environment with all other economic entities [12]. We consider it necessary to support this opinion because the key factor influencing profitability is really the mechanisms of market price formation, which depends on the direct margin of agricultural enterprises. Government support in this case really helps to regulate profitability through subsidy mechanisms and stimulate investment in the agricultural sector.

Also interesting are the theoretical scientific developments of I. Yu. Epifanova and V. Yakubiv in the field of research of the essence of profitability, states that profitability is an indicator that characterizes the efficiency of the enterprise in terms of its ability to make a profit and ensure effective reproduction of resources used. The profitability of the enterprise is characterized by the level of profit and profitability. Profit is an absolute indicator that does not take into account the costs incurred to obtain a certain result. Profitability is a relative indicator of the efficiency of the enterprise, which provides an opportunity to compare the result with the costs incurred [5, 23].

In practical terms, we support the opinion of J. Kocsis and K. Major, who argue that in todays Eastern and Central European countries, agricultural enterprises suffer from a lack of capital and unfavorable lending conditions, so the source of their profitability is innovative horticultural farms and large estates in crop production. It is argued that the essence of the agricultural enterprise's profitability depends not only on the amount of invested fixed capital, but also determined by the effectiveness of intangible assets of the enterprise [9].

Instead, B. Paskhaver argues that the key to ensuring a sufficient and stable level of profitability in the agricultural sector is to address the main macroeconomic problem of today's recovery and further growth of effective demand in the food market [18]. It should be noted that the agricultural sector, like other industries, cannot operate separately from market mechanisms, so its development depends not only on demand but also on the volume of 
investment in the capital of agricultural enterprises.

More pragmatic in this aspect is the position of $\mathrm{M}$. Parkhomets, who argues that the profitability of agricultural enterprises is based on technological, economic, and social components. Their essence is, respectively, in the use of production resources and the introduction of intensive technologies for the production of crop and livestock products; optimization of elements of the economic mechanism of management; implementation of measures for the development of social infrastructure of the enterprise [17]. Indeed, it is the interaction of available material and financial resources that results in increased efficiency and, consequently, agricultural enterprise's profitability.

However, it should be noted that there are a number of debatable issues regarding a comprehensive understanding of the economic content of enterprise profitability, as many studies are limited to the financial aspects of profitability, reducing research to determine profitability and related ratios.

In addition, despite considerable attention to this problem, a number of issues related to the identification of the main factors of increasing the profitability of agricultural enterprises in order to effectively use the resource potential of agricultural producers remain unresolved. Issues related to the study of the problem of price disparity, and the need for state intervention in the pricing process in the national agricultural market also remain problematic.

\section{Materials and Methods}

In the process of our research, we used a set of modern empirical and scientific-applied methods. In particular, to determine the nature and the role of profits in the development of agricultural enterprises, we used the method of analysis and synthesis. In order to identify the key factors that influence the efficiency of formation and use of the agricultural enterprise's profitability, we used the method of factor analysis in the study.

According to the results of the structural analysis method, the level of agricultural enterprise's profitability in terms of their organizational and legal forms of management, the scope of financial and economic activities as well as the unit of the occupied area, livestock, and taking into account the produced products. In addition, in the process of implementing our study, we used grouping methods to distribute the totality of the researched enterprises according to the special features of their functioning. According to the results of graphical and tabular methods, we were able to provide visually the research results on the agricultural enterprise's profitability in the Lviv region of Ukraine in 2016-2020.

In addition, the use of regression statistical analysis in the process of our study provided an opportunity to form and assess the reliability of construction and adequacy of regression model to assess the relationship of profit and revenue from agricultural enterprises with such factors as the capital ratio, the average annual amount of assets of enterprises, labour costs and the number of material costs per unit of land area.

\section{Results and Discussion}

Analysis of research by leading researchers and practitioners shows that profit should be considered as the end result of economic activity of the subject of economic activity, which reflects the effectiveness of its operation. However, as we know, the assessment of the performance of enterprises is more objective if it is carried out in dynamics and with the use of relative indicators. The reason for this is that different companies may receive different profits, as they have different resources, and their activities are characterized by different degrees of restrictions. Therefore, a more objective criterion for assessing the efficiency of agricultural enterprises should be to determine the rate of return.

The profitability of agricultural enterprises is essentially a complex, integrated, multifaceted economic category, which is characterized by a high degree of dependence on the influence of a complex of different factors. In this case, the system of formation and distribution of profits should take into account its complex, systemic and situational components. Therefore, the successful use of the organizational and economic mechanisms of profit generation provides an opportunity to create the conditions for high profitability of agricultural enterprises. Based on this, profitability should be interpreted as a specific condition of the entity, in which during a certain period there is an excess of its income over production costs, resulting in the generation of net operating cash flows, which represent the company's profit. 
Table 1. Dynamics of profitability of agricultural enterprises of the Lviv region by organizational and legal form for 2016 - 2020

\begin{tabular}{|c|c|c|c|c|c|c|}
\hline Years & Total & $\begin{array}{c}\text { Business } \\
\text { associations }\end{array}$ & $\begin{array}{c}\text { Private enterprises } \\
\text { (including large farms) }\end{array}$ & $\begin{array}{c}\text { Production } \\
\text { cooperatives }\end{array}$ & $\begin{array}{l}\text { Inter-farm } \\
\text { and others }\end{array}$ & State \\
\hline \multicolumn{7}{|c|}{ The share of profitable agricultural enterprises in their total number, $\%$} \\
\hline 2016 & 44 & 41 & 48 & 100 & 25 & 33 \\
\hline 2017 & 48 & 46 & 53 & 100 & 100 & 0 \\
\hline 2018 & 64 & 61 & 70 & 100 & 0 & 20 \\
\hline 2019 & 63 & 58 & 71 & 100 & 0 & 40 \\
\hline 2020 & 52 & 53 & 52 & 33 & - & 40 \\
\hline Change 2020 to $2016, \%$ & 22 & 25 & 3 & -50 & - & 7 \\
\hline \multicolumn{7}{|c|}{ Profitability of agricultural enterprises, \% } \\
\hline 2016 & 22.4 & 26.1 & 11.6 & 1.4 & -9.6 & -13.6 \\
\hline 2017 & 27.6 & 31 & 17.7 & 2.3 & 12.9 & -15.1 \\
\hline 2018 & 21.4 & 23.3 & 24.3 & 11.3 & - & 2.9 \\
\hline 2019 & 2.2 & -1.1 & 17 & -6.7 & - & 2.8 \\
\hline 2020 & 36.9 & 46.5 & 1.4 & -21.6 & - & 1.7 \\
\hline Change 2020 to $2016, \%$ & 13.6 & 11.3 & 18.9 & -7.7 & & 17.4 \\
\hline
\end{tabular}

* Source: [21]

Studies of the profitability of agricultural enterprises in the Lviv region, conducted for the period 2016-2020, made it possible to determine the intensity of development of agricultural enterprises in the region. However, one of the main features of the study of the dynamics of their number was that during the analyzed period, the number of medium and large agricultural companies in the region decreased by $20 \%$. Analysis of the financial aspects of the operation of these companies showed that one of the key reasons for this reduction was the loss, which led to the bankruptcy of some companies. However, the overall results of the operation of agricultural enterprises in the Lviv region showed that in 2020 there was an increase in the total area of agricultural land used by $36 \%$. In addition, there was an increase in crop production, which amounted to more than $75 \%$ compared to the beginning of the analyzed period. At the same time, the growth of production in the livestock industry amounted to $41 \%$. Thus, we can conclude that a significant increase in the production of marketable products by agricultural enterprises of the Lviv region was not only due to objective factors associated with increasing the intensity and efficiency of their production activities, but was due to extensive factors of expansion due to acquisition by large enterprises of their competitors, including those that went bankrupt during the analyzed period.

The results of the analysis of the dynamics of profitability of agricultural enterprises of the Lviv region in terms of taking into account the specifics of their organization by the form of ownership allowed determining certain specifics of differentiation of these enterprises by the level of profitability (Table 1).

As can be seen from the analysis, during the analyzed period, almost $50 \%$ of all agricultural enterprises operating in the form of companies and sole proprietorships were unprofitable. At the same time, the assessment of the level of profitability of all agricultural enterprises in the Lviv region shows that during the same period its value increased by $13.6 \%$. At the same time, it was the highest among companies - in particular, in 2020 the average profitability of their activities was $46.5 \%$, while private farms and state-owned agricultural enterprises recorded an average of $1.4 \%$ and $1.7 \%$. Finding out the reasons for such disparities in the final results of agricultural enterprises showed that the main reason for such a difference in levels of profitability is the scale, which gives companies greater access to credit and material resources and allows them to earn relatively more money per unit of output scale. Accordingly, agricultural joint-stock companies and limited liability companies demonstrate higher efficiency of economic activity, which encourages them to continue the policy of expanding their own activities in order to increase profits [6].

However, as noted above, one of the criteria that determine the effectiveness of economic and financial performance of enterprises is the limited access to resources. That is why the most effective in terms of reliability of evaluation of the results is the method of using relative indicators of economic and financial efficiency of enterprises (Fig. 1). 


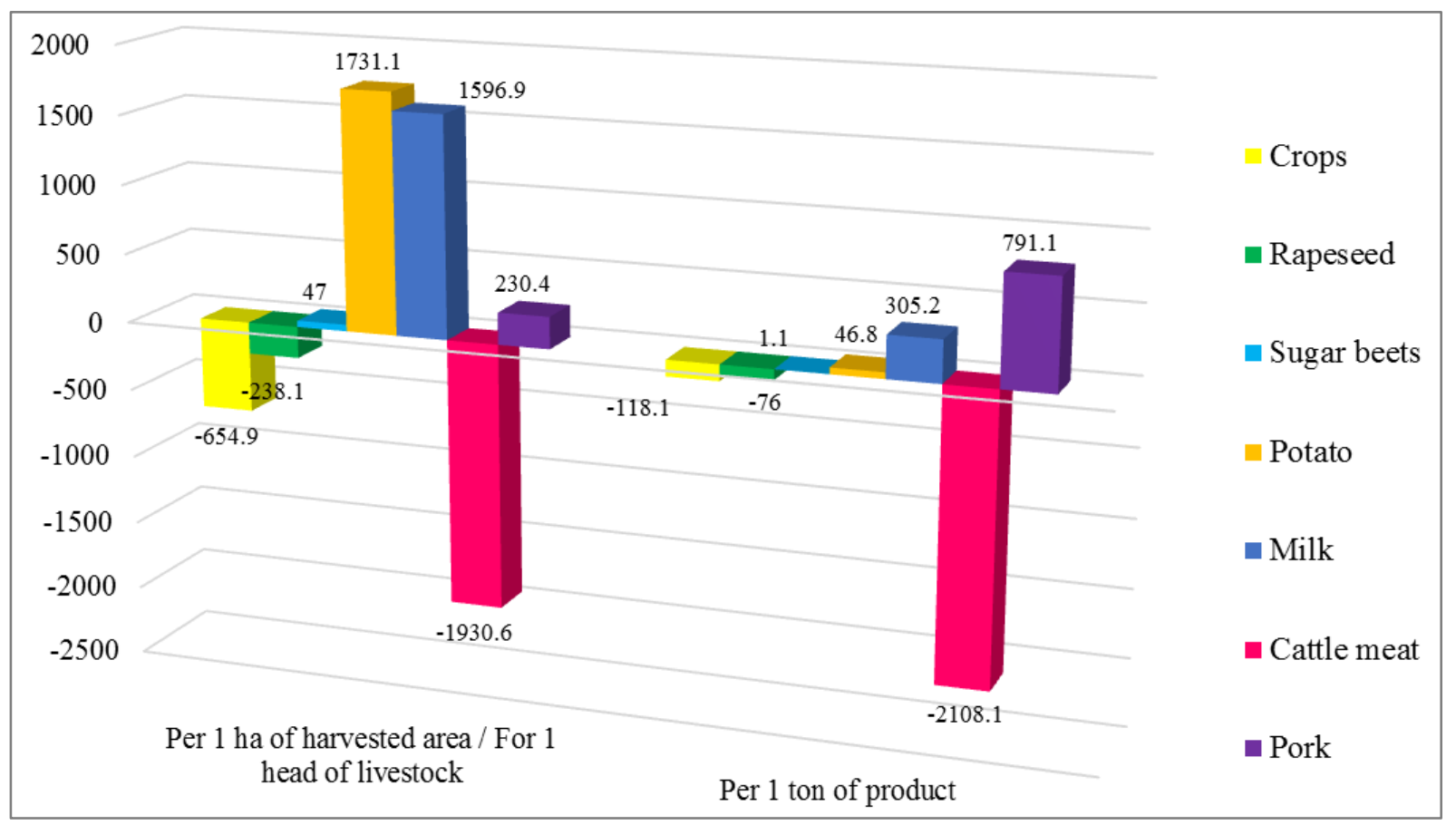

Source: calculated by the authors based on [21].

Figure 1. Profit of agricultural enterprises of the Lviv region per unit of area/livestock involved and per unit of output in 2020, UAH

Thus, based on the above analysis of the dynamics of profits of agricultural enterprises in the Lviv region, the overall efficiency of the use of available resources by these enterprises in 2020 was characterized as insufficient. Evidence of this is the loss of certain areas of agricultural enterprises and not too large values of profit per unit of output in key areas of agricultural production. At the same time, the market dynamics for this period indicate an overall increase in demand for agricultural products in this period, accompanied by rising prices for it.

In addition, the study identified the specifics of uneven efficiency of use of the land available to agricultural enterprises of the Lviv region. At the same time, the general economic principle, when better quality lands give more returns and, accordingly, enterprises receive a greater economic effect from their operation, did not always work in the process of activity of agricultural enterprises of the region. On the contrary, it was found that the effectiveness of such enterprises is determined primarily by the effectiveness of their management and administration when large companies make more effective decisions about the structure of production and the principles of sales. As a result, agricultural enterprises of different organizational and legal forms showed different levels of profitability and profitability in the analyzed period.

The analysis of sales of agricultural enterprises of the Lviv region in 2020 allowed us to determine such a feature that more than $60 \%$ of the total output comes to the final consumer only through intermediaries. At the same time, the specifics of regional agricultural companies show that it is more effective for such enterprises to focus on direct deliveries to sellers or directly to the final consumer, as it brings more profit and does not impose significant additional costs on agricultural enterprises for transportation. At the same time, the situation is similar in the field of processing of agricultural raw materials, where sales to direct consumers account for only $32.8 \%$ of total production. The practice of processing enterprises states that on the contrary - sales to end-users in such companies should be $65-70 \%$ of total production. Thus, it can be argued about the existing problems with ensuring the efficient sale of products by agricultural enterprises of the Lviv region, which directly affects the reduction of their profitability.

For completeness of the analysis, it is necessary to consider also features of change of level of profitability of agricultural production in the Lviv area as a whole for all analyzed periods (Fig. 2). 


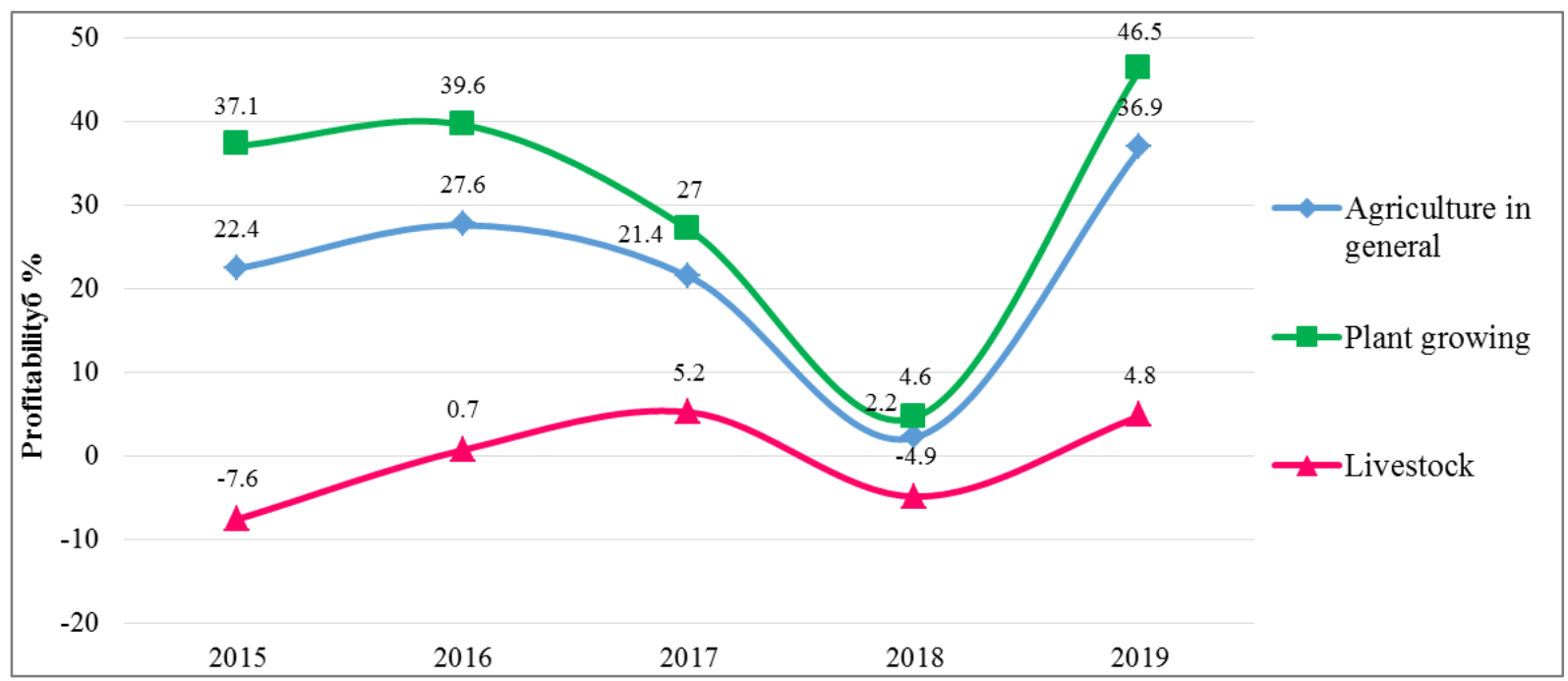

Source: calculated by the authors based on [21].

Figure 2. Dynamics of profitability of agricultural production in the Lviv region for $2016-2020$, \%

The analysis shows that during 2016-2019 there was a gradual decline in profitability of agricultural production. At the same time, its biggest drop occurred in 2019. However, in 2020 there was a sharp increase in the level of profitability in agriculture. This trend is explained by the general dynamics of agricultural profitability in Ukraine. The opening of solvent markets of the European Union in 2016-2017 for Ukrainian agricultural producers forced them to direct significant resources in the coming years to bring their products in line with EU standards. This resulted in an overall temporary decline in agricultural incomes. But starting in 2020, there is a reverse process - when sales of properly certified products give agricultural enterprises of Ukraine additional income, which leads to increased profits. Proof of this is the fact that although in the analyzed period the profitability of enterprises decreased, its overall level remained positive. It should also be noted that since the bulk of Ukrainian exports to new EU markets relate to the crop sector, the profitability indicators in this area showed a corresponding positive trend. But in animal husbandry, on the contrary - because the industry (except for poultry) is in decline, the value of its profitability is an order of magnitude lower and in some years the average final values indicate the loss of this area of agricultural production.

It is also worth noting that the overall profitability of agricultural enterprises in the Lviv region was significantly affected by such specifics as the presence of highly profitable agricultural holdings, which, due to sufficient financial resources and qualified management, show very high profitability and profitability. This somewhat distorts the results of the analysis, as the number of such companies at the regional level is measured in units, and the general trend in the dynamics of profitability of smaller companies is significantly different.

In addition, the analysis revealed that in the analyzed period of 2016-2020 in the Lviv region there were significant fluctuations in the level of profitability in various sectors of agricultural production. At the same time, in certain areas of agriculture, there was a steady trend towards unprofitable activities of enterprises in them (Table 2). 
Table 2. Dynamics of the level of profitability of agricultural enterprises of the Lviv region (Ukraine) for $2016-2020, \%$

\begin{tabular}{ccccccccc}
\hline Products & $\mathbf{2 0 1 6}$ & $\mathbf{2 0 1 7}$ & $\mathbf{2 0 1 8}$ & $\mathbf{2 0 1 9}$ & $\mathbf{2 0 2 0}$ & $\begin{array}{c}\mathbf{2 0 2 0} \text { to 2016 } \\
\text { (+/-; percentage } \\
\text { points) }\end{array}$ & $\begin{array}{c}\text { Agricultural enterprises that sold } \\
\text { products in 2020 } \\
\text { quantity, } \\
\text { units }\end{array}$ & $\begin{array}{c}\text { of which - the share of profitable in } \\
\text { the industry, \% }\end{array}$ \\
\hline All agricultural products & 22.4 & 27.6 & 21.4 & 2.2 & 36.9 & 14.5 & 186 & 51.6 \\
\hline Crop production & 37.1 & 39.6 & 27 & 4.6 & 46.5 & 9.4 & $\ldots$ & $\ldots$ \\
\hline Stock-breeding & -7.6 & 0.7 & 6.2 & -4.9 & 4.8 & 12.4 & $\ldots$ & $\ldots$ \\
\hline Corn & 13 & 4.5 & 8.3 & 4.3 & -10.5 & -23.5 & 132 & 53.8 \\
\hline Sugar beets & 101 & 56 & 29.2 & -3 & 0.2 & -100.8 & 16 & 62.5 \\
\hline Rapeseed & 88.6 & 80.6 & 63.1 & 15.2 & -2.4 & -91 & 78 & 66.7 \\
\hline Vegetables & 45.9 & 95.9 & 21.1 & 12.7 & 13.2 & -32.7 & 16 & 68.8 \\
\hline Potato & -23.1 & 41.2 & 26.1 & -39.3 & 3.4 & 26.5 & 22 & 63.6 \\
\hline Milk and dairy products & -27.5 & 15 & 23.6 & 3.2 & 15.8 & 43.3 & 28 & 14.3 \\
\hline Cattle meat & 4.1 & -36.4 & -19.1 & -27.2 & 38.8 & 34.7 & 42 & 16.7 \\
\hline Pork & 4.1 & 10.8 & 18.7 & -7.6 & 7.3 & 3.2 & 32 & 37.5 \\
\hline Poultry meat & -15.3 & 4 & 1.6 & -0.4 & 6.9 & 22.2 & 14 & 64.3 \\
\hline Eggs & -7.2 & -5.5 & -16.7 & 4.4 & 12.1 & 19.3 & 6 & 100.0 \\
\hline
\end{tabular}

Source: [21].

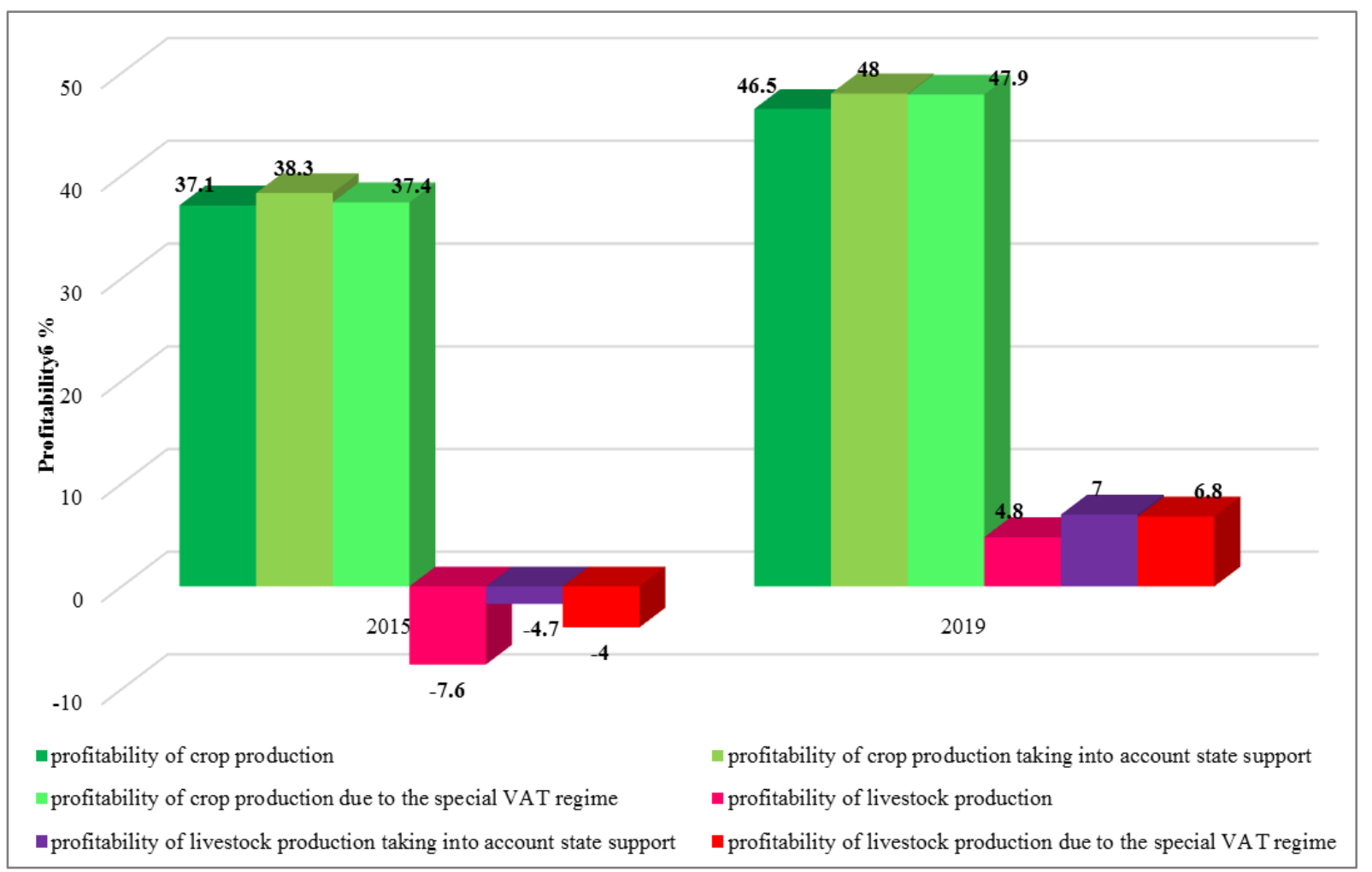

Source: calculated by the authors based on [21].

Figure 3. The impact of state financial support on the profitability of agricultural enterprises in Lviv region for 2016 - 2020

On the one hand, this is explained by the general trends observed in the field of agricultural production in Ukraine, when the focus on crop production is noticeable and the level of processing of agricultural raw materials at industrial enterprises is not deep enough. However, if we assess the specifics of the functioning of enterprises in the same sectors of agriculture, then there will be a difference in the levels of profitability of enterprises due to different resources and management systems.

In addition, it can be argued that in the analyzed period, 
the overall level of profitability of agricultural enterprises in the Lviv region was largely determined by state preferences for agricultural producers. This was manifested in the financing of subsidies for such enterprises (especially in the field of animal husbandry), as well as in the establishment of a special regime of value-added tax from agricultural enterprises that worked in priority sectors of each region (Fig. 3).

As the practice of these two main elements of state support for agriculture has shown, a special regime of VAT refunds was more effective for agricultural enterprises, as it resulted in the prompt allocation of financial resources to agricultural enterprises in the course of their operations. At the same time, subsidizing priority sectors of agricultural production, although performing the same function in terms of their financial incentives, in practice companies received these subsidies only after some time after the sale of manufactured products and before receiving government payments may have problems replenishing working capital.

However, despite the relative effectiveness of stimulating agricultural production through the establishment of a special tax regime for agricultural enterprises, it should be noted that the general reduction in mass state support for agriculture has reduced the efficiency of many agricultural enterprises in the Lviv region, especially in animal husbandry. However, the intensification of large agricultural holdings, which are constantly expanding their activities, on the contrary, gives them additional opportunities to use government support to their advantage due to the lack of significant problems with the implementation of key indicators necessary to obtain these preferences.

Thus, according to the results of the study, it can be argued that the profitability of agricultural enterprises in the Lviv region depends on the characteristics of their production specialization or versatility. At the same time, enterprises specializing in the production of crop products have a significantly higher level of profitability compared to enterprises specializing in animal husbandry. At the same time, enterprises that focus on narrow specialization in one or more types of products have a higher level of profitability than enterprises that focus on the differentiation of production. In addition, it should be noted that the share of unprofitable enterprises among all agricultural producers in the region is quite significant. In particular, in 2020 their number was about $40 \%$ of all agricultural enterprises in the Lviv region, which indicates the presence of problems with ensuring the efficiency of their operation.

To summarize, the identified trends correlation and regression analysis were conducted and both correlation and regression models were built (Table 3).

Table 3. Initial indicators for the construction of multifactorial correlation-regression models regarding the profitability of the agricultural enterprises in Lviv region in 2020

\begin{tabular}{|c|c|c|c|c|c|}
\hline Researched agricultural enterprises & $\begin{array}{l}\text { The profit from } \\
\text { agriculture } \\
\text { activity per unit } \\
\text { of agricultural } \\
\text { land thsnd. } \\
\text { UAH. / ha. }\end{array}$ & $\begin{array}{l}\text { The revenue } \\
\text { from agriculture } \\
\text { activity per unit } \\
\text { of agricultural } \\
\text { land, thsnd.. } \\
\text { UAH. / ha. }\end{array}$ & $\begin{array}{c}\text { The average } \\
\text { amount of assets } \\
\text { per unit of } \\
\text { agricultural } \\
\text { land, thsnd. } \\
\text { UAH. / ha. }\end{array}$ & $\begin{array}{c}\text { The labour costs } \\
\text { in agriculture } \\
\text { per unit of } \\
\text { agricultural } \\
\text { land, UAH. / ha. }\end{array}$ & $\begin{array}{c}\text { The material } \\
\text { costs of } \\
\text { agricultural } \\
\text { production per } \\
\text { unit of } \\
\text { agricultural } \\
\text { land, thsnd. } \\
\text { UAH. / ha. } \\
\end{array}$ \\
\hline Private enterprise "Sasiv-Agro" & 1.15 & 3.17 & 0.51 & 93.88 & 1.60 \\
\hline Private enterprise "Western Bug" & 0.31 & 1.00 & 25.83 & 445.88 & 0.39 \\
\hline Agrofirm Vatra LLC & 0.63 & 6.26 & 3.16 & 463.18 & 6.10 \\
\hline Private enterprise "Agricultural firm "Dzvony" & 0.42 & 4.30 & 9.95 & 140.60 & 3.79 \\
\hline Private agricultural enterprise "Bohdan" & -0.26 & 2.86 & 12.64 & $1,320.09$ & 1.96 \\
\hline Taras Shevchenko Agricultural LLC & -6.03 & 7.29 & 9.31 & $1,696.99$ & 5.72 \\
\hline Private enterprise "Agricultural firm Lugove" & -0.26 & 0.36 & 7.03 & 488.24 & 0.47 \\
\hline Mezhyrichchia Farm & -1.14 & 1.03 & 19.62 & 130.22 & 0.39 \\
\hline Agrotuchapi LLC & 0.19 & 7.07 & 6.06 & 142.30 & 6.05 \\
\hline Agricultural LLC "Kameniar" & 0.02 & 8.53 & 8.20 & 504.98 & 4.21 \\
\hline Markiyan Shashkevych LLC & 0.39 & 5.57 & 13.97 & 564.51 & 3.23 \\
\hline Farm "Oasis K" & 0.18 & 0.48 & 9.91 & 69.74 & 0.05 \\
\hline Agricultural LLC "Dnister" & 0.01 & 2.62 & 5.84 & 775.64 & 1.45 \\
\hline Skyba C LLC & -2.50 & 4.31 & 24.96 & $2,854.51$ & 3.01 \\
\hline Private enterprise "Agricultural firm "Hlibodar" & -0.07 & 2.25 & 9.14 & 255.97 & 2.08 \\
\hline Lelik Farm & -1.37 & 7.39 & 9.95 & 510.15 & 4.25 \\
\hline Farm "Agroosnova" & 3.26 & 13.01 & 24.80 & $2,198.66$ & 9.57 \\
\hline Farm "Godov V. + RE" & -1.15 & 5.01 & 2.31 & 590.07 & 3.08 \\
\hline Marichka Farm & -40.14 & 4.39 & 9.88 & $1,786.52$ & 4.00 \\
\hline Pidiarkiv Farm & 0.06 & 0.14 & 1.59 & 12.01 & 0.10 \\
\hline
\end{tabular}


Table 3 Continued

\begin{tabular}{|c|c|c|c|c|c|}
\hline LLC "V.D.S. Agro" & 1.22 & 6.17 & 13.36 & 765.88 & 5.42 \\
\hline Agricultural Production Cooperative V. Stefanyk & 0.16 & 2.75 & 8.56 & 100.66 & 1.86 \\
\hline Terranova-Agro LLC & -0.64 & 25.37 & 170.4 & $2,182.39$ & 15.11 \\
\hline Barcom LLC & -0.12 & 0.29 & 2.98 & $1,121.65$ & 2.62 \\
\hline Pidhirtsi LLC & -3.81 & 1.97 & 9.70 & 481.53 & 2.80 \\
\hline Private agricultural firm "White Stick" & -5.76 & 3.94 & 14.16 & 603.11 & 6.67 \\
\hline LLC "Galicia - West" & -2.58 & 12.59 & 19.15 & $4,196.83$ & 4.51 \\
\hline Private enterprise "Kobryn" & 0.31 & 5.25 & 3.45 & 753.94 & 5.73 \\
\hline Private enterprise "Hlyniany Agro" & 2.25 & 49.58 & 77.26 & $2,912.36$ & 46.80 \\
\hline Farm "Start" & 0.54 & 6.67 & 12.28 & 178.12 & 1.83 \\
\hline Private agricultural firm "Halytska" & -4.12 & 10.00 & 119.5 & 63.43 & 5.09 \\
\hline Peasant farm "Dzvin" & 0.23 & 3.90 & 7.02 & 52.11 & 3.68 \\
\hline Farm "Mercury" & 0.00 & 0.26 & 0.24 & 27.64 & 0.13 \\
\hline Agro Radekhiv LLC & -0.25 & 7.45 & 10.62 & 253.13 & 3.08 \\
\hline Farm "Maksymovych" & -0.91 & 2.30 & 4.15 & 48.66 & 0.39 \\
\hline Farm "Golden Autumn" & 1.04 & 9.05 & 14.99 & 847.17 & 5.38 \\
\hline Private enterprise "Agrofirm" B. Khmelnytsky" & -0.92 & 2.62 & 8.53 & 915.07 & 1.75 \\
\hline LLC "Khlibodar" & -0.32 & 2.30 & 1.59 & 708.53 & 1.35 \\
\hline Agro-Lan LLC & -0.12 & 0.76 & 5.28 & 66.45 & 0.91 \\
\hline Private agricultural firm "Zbizhzhia" & 0.32 & 11.28 & 13.03 & 390.04 & 6.02 \\
\hline Apogee Agro LLC & -0.02 & 1.60 & 5.00 & 573.50 & 2.40 \\
\hline Farm "Zakhid-Ptycia" & 1.23 & 4.30 & 7.29 & 495.27 & 3.30 \\
\hline Pereveslo Farm & 1.37 & 5.17 & 55.61 & 693.65 & 1.01 \\
\hline Yuzepivka Farm & 0.94 & 5.86 & 10.43 & 309.88 & 5.01 \\
\hline Private agricultural firm "Peremoga" & 0.59 & 3.86 & 1.59 & 169.84 & 2.28 \\
\hline Farm "Bogdan-M" & 1.55 & 10.69 & 51.87 & $1,138.62$ & 8.00 \\
\hline Private rental company "Nakonechne" & 0.69 & 7.57 & 6.78 & 316.56 & 5.59 \\
\hline Private enterprise "Cosatskyi kurin" & 0.61 & 8.59 & 16.13 & $1,612.01$ & 8.25 \\
\hline Agricultural LLC "Dovira" & 0.02 & 1.42 & 2.82 & 364.91 & 0.64 \\
\hline Farm "Zodiac-M" & -0.08 & 3.03 & 4.02 & 216.83 & 2.87 \\
\hline Farm "Chance" & -0.10 & 1.39 & 2.32 & 545.06 & 13.37 \\
\hline Private enterprise "Shostak" & -0.77 & 6.36 & 6.05 & 204.38 & 6.11 \\
\hline Farm "Golden Field +" & -0.09 & 0.53 & 2.29 & 205.08 & 0.34 \\
\hline Spikolos Farm & -0.08 & 0.28 & 0.51 & 75.90 & 0.27 \\
\hline Private enterprise "Horizon" & -0.88 & 3.13 & 5.26 & 896.49 & 2.70 \\
\hline LLC "Agro LV Limited" & -0.23 & 3.19 & 5.83 & $1,341.16$ & 3.47 \\
\hline Farm "Field of Gold" & 1.01 & 2.27 & 17.0 & 152.77 & 0.81 \\
\hline LLC "Ordiv-Agro" & 0.01 & 0.40 & 2.20 & 175.21 & 1.29 \\
\hline Vyatichi Farm & -0.03 & 2.70 & 7.37 & 343.32 & 2.03 \\
\hline Agrotech LLC & 11.49 & 77.15 & 153.9 & $2,009.98$ & 10.43 \\
\hline Private enterprise Agrofirm "Agrotrade" & 0.61 & 1.32 & 16.83 & 123.41 & 0.28 \\
\hline LLC "Danuta" & -1.17 & 3.49 & 4.73 & $1,916.28$ & 2.47 \\
\hline Dubrova Farm & -0.46 & 0.41 & 3.02 & 147.85 & 0.10 \\
\hline
\end{tabular}

Source: [21].

The following factors were selected: the amount of average annual assets (x1), labour costs (x2) and material costs of agricultural production (x3) per 1 hectare of the occupied agricultural land and the measure of their impact on the amount of profit (y1) and the revenue from agricultural activities (y2), that are received per one 1 hectare of farmland was determined.

The regression equation is as follows:

$$
\begin{gathered}
y_{1}=-5.44386+0.33937 x_{1}-0.00133 x_{2}+0.10177 x_{3} ; \\
y_{2}=-39.4809+2.2591 x_{1}+0.0056 x_{2}+0.6434 x_{3} .
\end{gathered}
$$


Table 4. Matrix of coefficients of pair correlation between the factorial features and effective indicators of the constructed correlation-regression models

\begin{tabular}{|c|c|c|c|c|c|}
\hline & $\begin{array}{c}\text { The average } \\
\text { annual amount } \\
\text { of assets per } \\
\text { unit of } \\
\text { agricultural } \\
\text { land, thsnd. } \\
\text { UAH. / ha. }\end{array}$ & $\begin{array}{c}\text { The labour costs } \\
\text { in agricultural } \\
\text { per unit of } \\
\text { agricultural } \\
\text { land, UAH. / ha. }\end{array}$ & $\begin{array}{c}\text { The revenue } \\
\text { from } \\
\text { agriculture per } \\
\text { unit of } \\
\text { agricultural } \\
\text { land, thsnd. } \\
\text { UAH. / ha. } \\
\end{array}$ & $\begin{array}{l}\text { The profit from } \\
\text { agricultural } \\
\text { activity per unit of } \\
\text { farmland. thsnd. } \\
\text { UAH. / ha. }\end{array}$ & $\begin{array}{l}\text { The material costs of } \\
\text { agricultural } \\
\text { production } \\
\text { per unit of } \\
\text { agricultural land, } \\
\text { thsnd. UAH. / ha. }\end{array}$ \\
\hline $\begin{array}{c}\text { The average annual amount of } \\
\text { assets per unit of agricultural land, } \\
\text { thsnd. UAH. / ha. }\end{array}$ & 1.00 & 0.21 & 0.46 & 0.24 & 0.31 \\
\hline $\begin{array}{l}\text { The labour costs in agriculture per } \\
\text { unit of agricultural land, UAH. / ha. }\end{array}$ & 0.21 & 1.00 & 0.45 & 0.04 & 0.15 \\
\hline $\begin{array}{c}\text { The revenue from agricultural per } \\
\text { unit of agricultural land, thsnd. } \\
\text { UAH. / ha. }\end{array}$ & 0.46 & 0.45 & 1.00 & 0.89 & 0.80 \\
\hline $\begin{array}{l}\text { The profit from agricultural activity } \\
\text { per unit of farmland. thsnd. UAH. / } \\
\text { ha. }\end{array}$ & 0.24 & 0.04 & 0.89 & 1.00 & 0.71 \\
\hline $\begin{array}{c}\text { The material costs of agricultural } \\
\text { production per unit of agricultural } \\
\text { land, thsnd. UAH. / ha. }\end{array}$ & 0.31 & 0.15 & 0.80 & 0.71 & 1.00 \\
\hline
\end{tabular}

According to the results of the research, the coefficients of determination (0.99) and of the multiple correlation (0.99) for two dependencies indicate a high level of influence of selected factors on effective indicators and density of the detected correlation between them.

The value of $\mathrm{F}_{\text {critical }}$ - calculated F-test for the received correlation models for the given degrees of freedom and $\alpha$ $=0,001$, meets condition $\mathrm{F}_{\text {critical }}>\mathrm{F}_{\text {tabular }}$, indicating the statistical significance of the constructed models, their representativeness and the suitability for analysis and forecasting.

The calculation of coefficients of pair correlation was conducted that confirms the correctness of selection of the researched factor features and effective indicators, as well as a representation and the adequacy of constructed multifactorial regression models (Table 4).

According to the results of the study we proved, that the constructed multifactorial correlation and regression models allow us to make the conclusion about availability of the significant impact on the profitability of the security of the agricultural enterprises in Lviv region and the level of their intensification of the production activities.

\section{Conclusions}

Thus, based on the study, it can be argued that the profit of agricultural enterprises is a key indicator for the implementation of the process of agricultural production, and is one of the main criteria for the effectiveness of the agricultural sector. In addition, the profit of agricultural enterprises acts as a basic source of financial resources that the company can direct to invest in its own development and renewal of fixed assets. At the same time, the presence of profit as a financial result of agricultural enterprises, in the long run, allows them to direct part of it to ensure sustainable development of rural areas, which also contributes to their overall socio-economic development and improves living conditions in rural areas. Thus, the profit of agricultural enterprises ensures not only the proper functioning of the system of agricultural production but also contributes to the effective development of commodity markets for agricultural products. Based on this, we can say about its key role in shaping the profitability and profitability of agricultural enterprises.

Accordingly, speaking about the profitability of agricultural enterprises, it should be noted that it is a specific financial condition of the enterprise, for which it can provide regular inflows of financial resources from both operating activities and other activities. The consequence of such revenues is a financial result in which the total income of the agricultural enterprise exceeds the costs incurred. It is on the basis of fixing such a financial result that it is possible to ensure the proper efficiency of the economic activity of agricultural enterprises. Thus, it can be argued that profitability is the main criterion for the efficiency of agricultural enterprises.

As the results of the analysis of the profitability of agricultural enterprises of the Lviv region for 2017 - 2020 show, there is a significant differentiation of these enterprises by their level of profitability, which directly affects the overall performance of their operation and affects the socio-economic situation in the region. It is determined that the activity of agricultural enterprises is significantly influenced by external factors that are not directly related to the production activities of enterprises. These factors mainly include not only seasonal fluctuations in market prices, but are also associated with unpredictable 
trends in supply and demand in the global food market, which prevents agricultural enterprises from responding effectively to such changes and leads to a loss of potential profits. On the other hand, the task of smoothing such fluctuations is one of the main tasks of the state as a market regulator, which requires improving the existing tools to influence price fluctuations. If we talk about the positive aspects that affect the profitability of agricultural enterprises, they should include the availability of specialized support programs for agricultural producers, which are offered through government subsidies, as well as a system of tax incentives for agricultural enterprises, which is used to increase their investment opportunities.

\section{REFERENCES}

[1] Andrijchuk, V. H., Zubets, M. V., Yurchyshyn, V. V. "Modern agricultural policy: Problematic aspects," Kyiv, Agricultural Science, 2005.

[2] Antoniuk, R. R. "Profitability of agricultural enterprises: the nature of the category," Bulletin of Kharkiv National Technical University of Agriculture, Vol. 126, pp. 50-55, 2012.

[3] Berzhanir, I. A., Ulianych, Y. V., Gvozdey, N. I. "Profitability as the main indicator of the enterprise," Bulletin of KhNDAU, Vol. 1, pp. 261-265, 2015.

[4] Dziamulych, M., Shmatkovska, T., Krupka, M., Yastrubetska, L., Vyshyvana, B., Derevianko, S. "Introduction of NSFR Ratio in the Activities of Commercial Banks in Ukraine," Universal Journal of Accounting and Finance, Vol. 9, No. 6, pp. 1544 - 1550, 2021. DOI: 10.13189/ujaf.2021.090631.

[5] Epifanova, I. Y., Humeniuk, V. S. "Profitability of the enterprise: modern approaches to defining the essence," Economy and society, Vol. 3, pp. 189-192, 2016.

[6] Halkiv, L. I., Karyy, O. I., Demchyshyn, M. Y. "Bank crediting within the structure of national economy of Ukraine: Parametric evaluation and problems with activation," Actual problems of economics, Vol. 180(6), pp. 314-320, 2016.

[7] Khmelevskyi, O. V. "Estimation of quality of profitability in innovation and investment development of machine-building enterprises," Economist, Vol. 3, pp. 50-53, 2008.

[8] Khorunzhiy, M. Y. "Problems of pricing for agricultural products," Agro-industrial complex, Vol. 1, pp. 57-61, 2011.

[9] Kocsis, J., Major, K. “A General Overview of Agriculture and Profitability in Agricultural Enterprises in Central Europe," Managing Agricultural Enterprises, 243-265,
2018. DOI: 10.1007/978-3-319-59891-8_12

[10] Kostyrko, L. A., Chernodubova, E. V. "The adaptive mechanism to ensure of the financial profitability," Journal of Economic Reforms, Vol. 4, pp. 56-61, 2014.

[11] Lakhtionova, L. A. "Financial analysis of agricultural enterprises,” Kyiv, KNEU, 2004.

[12] Melnyk L. L. "Profitability of agricultural enterprises as a factor in ensuring their sustainable socio-economic development," Agrosvit, Vol. 11, pp. 5-11, 2015.

[13] Melnyk, L. Yu., Makarenko, P. M., Melnyk, L. L. "Factors influencing the profitability of agricultural enterprises," Economics of agro-industrial complex, Vol. 5, pp. 79-86, 2010.

[14] Mochernyi, S. V., Mocherna, J. S. "Political economy," Kyiv, Znannia, 2007.

[15] Ohiichuk, M. F. "The essence of profit and approaches to the methodology of its definition," Economics of agro-industrial complex, Vol. 6, pp. 31-45, 2009.

[16] Osypova, T. V. "Theoretical aspects of the interpretation of profitability in modern business conditions," Development management, Vol. 1, pp. 82-84, 2012.

[17] Parkhomets, M. K., Gudak, V. V. "Organizational and economic mechanism of ensuring the profitability of agricultural enterprises: theory, methodology, practice," Ternopil, TNEU, 2014.

[18] Paskhaver, B. Y. "Profitability and profitability of agricultural enterprises in the inflation process," Economics and forecasting, Vol. 3, pp. 66-76, 2016.

[19] Sabluk, P. T. "Agro-industrial complex economic mechanism in a market economic system," Economics of Agro-industrial complex, Vol. 2, pp. 5-10, 2007.

[20] Stashchuk O., Shmatkovska T., Dziamulych M., Nikolaeva A., Mostovenko N., Zabedyuk M. Ishchuk L. "Assessment of joint stock companies finance security risks in Ukraine," Accounting, Vol. 6(7), pp. 1181-1192, 2020. DOI: 10.5267/j.ac.2020.9.009.

[21] State Statistics Service of Ukraine, Online available from http://www.ukrstat.gov.ua.

[22] Zhmajlov, V. M., Zhmajlova, O. H., Babytska, O. O. "Organizational-economic bases of profit management of agricultural enterprises," Sumy, SNAU, 2014.

[23] Yakubiv, V., Sodoma R., Hrytsyna, O., Pavlikha, N., Shmatkovska, T., Tsymbaliuk, I., Marcus, O., Brodska, I. "Development of electronic banking: a case study of Ukraine," Entrepreneurship and Sustainability Issues. Vol. 7(1), pp. 219-232, 2019. DOI: 10.9770/jesi.2019.7.1(17)

[24] Yurchyshyn, V. "By analyzing the causes and consequences of the decline of agriculture," Economy of Ukraine, Vol. 2, pp. 54-63, 2001. 